\title{
PENGARUH KONSENTRASI GARAM TERHADAP UJI ORGANOLEPTIK KIMIA KEONG KOWOE (Pila ampullacea) PINDANG SELAMA PENYIMPANAN
}

\author{
The Effect Salt Concentration to Organoleptic Tests and Chemical Content Pindang Kowoe Snail (Pila ampullacea) Pring \\ Storage
}

\author{
Eko Bramatya, Moh. Nuh Ibrahim, Kobajashi T. Isamu \\ Jurusan Teknologi Hasil Perikanan, Fakultas Perikanan dan Ilmu Kelautan Universitas Halu Oleo, Kendari, \\ Sulawesi Tenggara, Indonesia \\ *Email korespondensi: ekobramatya@gmail.com (Telp: +6285341792095) \\ Diterima: 3 Juli 2019/ Disetujui: 15 Agustus 2019
}

Cara sitasi: Bramatya E, Ibrahim MN, Isamu KT. 2019. Pengaruh konsentrasi garam terhadap uji organoleptik kimia keong kowoe (Pila ampullacea) pindang selama penyimpanan. Jurnal Fish Protech. 2(2):189-195.

\begin{abstract}
The aims of this study was to determine the effect of salt concentration on the organoleptic test of the chemical snail kowoe (pila ampullacea) pindang during storage. This research was conducted at the Laboratory of Fisheries Technology Department of the Faculty of Fisheries and Marine Sciences, University of Halu Oleo (UHO). This study used a completely randomized design (CRD) consisting of salting with a concentration of $8 \%$, salting with a concentration of $19 \%$, and salting with a concentration of $27 \%$ with three replications. Based on the results of the study on the effect of salt concentration showed that the highest taste value at treatment $N 1$ was 6 (quite like), the highest water content in treatment N3 was $82.60 \%$, ash content at N3 treatment was $7.19 \%$, protein content in treatment N1 was $14.30 \%$, fat content at N1 treatment was $1.18 \%$ and carbohydrate content in N3 treatment was $6.53 \%$, the effect of storage time showed that the highest water content in treatment $\mathrm{T} 1$ was $79.03 \%$, ash content in T3 treatment was $6.39 \%$, protein content in treatment $T 1$ was $12.35 \%$, fat content in treatment $T 1$ was $0.93 \%$ and carbohydrate content in treatment $T 1$ was $5.79 \%$ and the interaction of salt concentration and storage time showed that the mean value of appearance, smell, taste and texture was obtained the highest value in a row ie at N1T1 treatment of 5 (enough likes), N1T1 treatment is 5 (quite like), N1T2 treatment is 7 (likes), N1T1 treatment is 5 (likes), as long as $n$ the water content, ash, protein, fat and carbohydrate obtained the highest levels in a row namely at N3T1 treatment of $83.34 \%, N 3 T 3$ treatment at $7.23 \%, N 1 T 1$ treatment at $14.44 \%$, at N1T1 treatment at $1.18 \%$ and $N 3 T 1$ treatment at $6.87 \%$.
\end{abstract}

Keywords: Kowoe Snail, Salting, Proximate, Organoleptic

\section{ABSTRAK}

Tujuan penelitian ini adalah untuk mengetahui pengaruh konsentrasi garam terhadap uji organoleptik kimia keong kowoe (Pila ampullacea) pindang selama penyimpanan. Penelitian ini dilaksanakan di Laboratorium Jurusan Teknologi Hasil Perikanan Fakultas Perikanan dan IImu Kelautan UniversitasHalu Oleo (UHO).Penelitian ini menggunakan Rancangan Acak Lengkap (RAL) yang terdiri penggaraman dengan konsentrasi 8\%, penggaraman dengan konsentrasi $19 \%$, dan penggaraman dengan konsentrasi $27 \%$ dengan tiga kali ulangan. Berdasarkan hasil penelitian terhadap pengaruh konsentrasi garam menunjukkan bahwa nilai rasa tertinggi pada perlakuan N1 sebesar 6 (cukup suka), kadar air tertinggi pada perlakuan N3 sebesar $82.60 \%$, kadar abu pada perlakuan N3 sebesar $7.19 \%$, kadar protein pada perlakuan N1 sebesar $14.30 \%$, kadar lemak pada perlakuan N1 sebesar $1.18 \%$ dan kadar karbohidrat pada perlakuan N3 sebesar $6.53 \%$, pengaruh lama penyimpanan menunjukkan bahwa kadar air tertinggi pada perlakuan T1 sebesar $79.03 \%$, kadar abu pada perlakuan T3 sebesar $6.39 \%$, kadar protein pada perlakuan T1 sebesar 12.35\%, kadar lemak pada perlakuan $\mathrm{T} 1$ sebesar $0.93 \%$ dan kadar karbohidrat pada perlakuan $\mathrm{T} 1$ sebesar $5.79 \%$ dan interaksi konsentrasi garam dan lama penyimpanan menunjukkan bahwa rerata nilai rupa, bau, rasa dan tekstur diperoleh nilai tertinggi berturut-turut yakni pada perlakuan N1T1 sebesar 5 (cukup suka), perlakuan N1T1 sebesar 5 (cukup suka), perlakuan N1T2 sebesar 7(suka), perlakuan N1T1 sebesar 5 (cukup suka), sedangkan kadar air, abu, protein, lemak dan karbohidrat diperoleh kadar tertinggi berturut-turut yakni pada perlakuan N3T1 sebesar $83.34 \%$, perlakuan N3T3 sebesar $7.23 \%$, perlakuan N1T1 sebesar $14.44 \%$, pada perlakuan N1T1 sebesar 1.18\% dan perlakuan N3T1 sebesar $6.87 \%$. 
Kata kunci: Keong Kowoe, Penggaraman, Proksimat, Organoleptik

\section{PENDAHULUAN}

Keong kowoe (Pila ampullacea) merupakan jenis keong yang dikonsumsi oleh masyarakat. Pengolahan keong kowoe untuk dikonsumsi di proses dengan pemberian konsentrasi garam sama seperti pada proses penggaraman telur asin dengan kadar $2 \%$ sampai 5\% (Safrullah, 2003). Penggaraman pada ikan bandeng dilakukan dengan kadar garam 9\%, 18\% dan $27 \%$ untuk memperoleh kualitas ikan bandeng yang diinginkan (Patang dan Yunarti, 2014) Pemberian garam ini ditujukan untuk meningkatkan kualitas protein pada daging ikan.

Proses penggaraman kepada bahan makanan seperti keong kowoe merupakan sama seperti pada ikan bandeng dan telur asin. Peran penggaraman sebagai pengawet dan mempertahankan protein pada sumber makanan sehingga dapar dikonsumsikan. Proses penggaraman dilakukan sesuatu kebutuhan bahan, karena tidak semua proses penggaraman dapat perlakukan yang sama. Perlakukan penggaraman pada daging dapat diamati dalam beberapa hari dengan tujuan untuk mengetahui tekstur protein dalam ikan bandeng dan telur asin tersebut. Hal serupa dapat dilakukan pada keong kowoe.

Menurut Wardhono (2012), keong kowoe (Pilaampullacea) adalah sejenis siput air tawar dan mudah dijumpai di sawah. Bentuknya menyerupai siput keong mas (murbai), tetapi keong kowoe memiliki warna cangkang hijau pekat sampai hitam. Hewan ini dikonsumsi secara luas di berbagai wilayah Asia Tenggara dan memiliki nilai gizi yang baik karena mengandung protein yang cukup tinggi. Kandungan gizi keong kowoe antara lain protein $15 \%$, lemak 2,4\%, kadar abu $24 \%$.

Perebusan adalah cara memasak makanan dalam cairan yang sedang mendidih $\left(100^{\circ} \mathrm{C}\right)$. Bahan pangan yang dimasak menggunakan air akan

Prosedur pembersihan, perebusan dan penggaraman keong kowoe sebagai berikut Tahap pertama, bahan mentah berupa keong kowoe meningkatkan daya kelarutan. Pemanasan dapat mengurangi daya tarik-menarik antara molekul-molekul air dan akan memberikan cukup energi pada molekul air sehingga dapat mengatasi daya tarik menarik antar molekul dalam bahan pangan (Winarno, 2008).

Proses perebusan yang dilakukan terhadap keong kowoe merupakan proses untuk menguraikan zat-zat yang beracun pada keong tersebut dan ditambahkan dengan konstrasi garam, kemudian dikajikan dengan karakteristik dan kimia. Selama ini proses keong kowoe hanya direbut dengan air dan ditambahkan garam setelah itu diberikan dan diolah untuk menjadi bahan makan. Peran penting garam dalam perebusan menjadi bagi yang harus dikaji sehingga diperoleh pemahaman terhadap pengolahan keong kowoe dengan baik (Winarno, 2008).

\section{METODE PENELITIAN}

\section{Alat dan Bahan}

Bahan yang akan digunakan terdiri atas bahan utama dan bahan pendukung. Bahan utama adalah daging keong kowoe Bahan kimia dan pereaksi yang digunakan adalah petroleum eter, $\mathrm{H}_{2} \mathrm{SO}_{4}, \mathrm{NaOH}$, etanol, $\mathrm{HCl}, \mathrm{CuSO}_{4}$, indikator metil merah, indikator metil biru, asam oksalat, aquades, dan pereaksi anthrone.

Peralatan yang digunakan dalam penelitian ini adalah: baskom, pisau, blender, panci, kompor. Peralatan analisis yang digunakan antara lain neraca analitik, desikator, cawan porselin, peralatan soxhlet, labu Kjeldhal, buret, peralatan destilasi, spektrofotometer Genesis 20, dan peralatan gelas.

disediakan sebanyak $3 \mathrm{~kg}$. Dilanjutkan ke proses pembersihan yaitu dengan cara perendaman keong kowoe selama kurang lebih 2 malam untuk 
membersihkan pasir dan lumut yang melekat pada cangkang dan daging. Tahapan kedua adalah proses perebusan. Dalam proses ini dilakukan pembagian wadah perebusan dengan konstraksi garam yang berbeda-beda yaitu wadah 1 sebangak $1 \mathrm{~kg}$ keong kowoe diberi kadar garam sebanyak $9 \%$, wadah 2 sebangak $1 \mathrm{~kg}$ keong kowoe diberi kadar garam sebanyak $18 \%$ dan wadah 3 sebangak $1 \mathrm{~kg}$ keong kowoe diberi kadar garam sebanyak $27 \%$. Tahapan ketiga adalah proses analisa melalui uji organoleptif dan uji proksimat.

\section{Penilaian organoleptik}

Penilaian organoleptik terhadap produk kowoe pindang meliputi warna, tekstur, aroma dan rasa dengan menggunakan skala sensorik. Pengujian ini menggunakan 20 orang panelis semi terlatih.

\section{Analisis kimia Kowoe Pindang}

HASIL DAN PEMBAHASAN

\section{Uji Organoleptik}

Rekapitulasi analisis ragam pengaruh konsentrasi garam $9 \%, 18 \%, 27 \%$, dan lama penyimpanan 0 hari, 1 hari, dan 2 hari terhadap
Analisis kimia meliputi analisis kadar air, analisis kadar abu, analisis kadar protein, analisis kadar kabohidrat dan analisi kadar lemak (AOAC, 2005).

\section{Rancangan Penelitian}

Penelitian ini menggunakan Rancangan Acak Lengkap (RAL), pola faktorial yaitu faktor penyimpanan dan faktor konsentrasi garam . Rancangan ini diulangi 3 kali pengulangan sehingga unit percobaannya ada 27 Unit Percobaan.

\section{Analisis Data}

Data dianalisis dengan menggunakan sidik ragam (Analysis of Varian), hasil uji organoleptik berpengaruh nyata terhadap variabel pengamatan, maka dilanjutkan dengan uji Duncan's Multiple Range Test (DMRT) pada taraf kepercayaan $95 \%(\alpha=0,05)$.

parameter kesukaan panelis yang meliputi warna, aroma, tekstur dan rasa serta uji nilai gizi yang meliputi kadar air. Kadar abu, kadar protein, kadar lemak dan kadar karbohidrat pada perebusan keong kowoe disajikan pada Tabel 1.

Tabel 1. Rekapitulasi hasil rerata analisis ragam dari semua variabel yang dilakukan.

\begin{tabular}{|c|c|c|c|c|c|c|c|c|c|}
\hline \multirow{2}{*}{$\begin{array}{c}\text { Variabel } \\
\text { Pengamatan }\end{array}$} & \multicolumn{9}{|c|}{ Perlakuan } \\
\hline & NIT1 & N1T2 & N1T3 & N2T1 & N2T2 & N2T3 & N3T1 & N3T2 & N3T3 \\
\hline Uji Sensori & & & & & & & & & \\
\hline a. Rupa & 5,43 & 5,99 & 5,85 & 6,04 & 6,35 & 6,39 & 6,24 & 6,04 & 6,28 \\
\hline b. Aroma & 5,45 & 6,01 & 5,85 & 6,04 & 6,29 & 6,39 & 6,24 & 6,04 & 6,17 \\
\hline c. Tekstur & 5,40 & 5,83 & 5,83 & 6,04 & 6,29 & 6,52 & 6,24 & 6,01 & 6,20 \\
\hline d. Rasa & 6,04 & 6,65 & 6,17 & 6,28 & 6,21 & 6,12 & 5,66 & 5,32 & 5,21 \\
\hline
\end{tabular}

\section{Rupa}

Hasil analisis anova (analysis of variance) terhadap pengaruh interaksi konsentrasi garam dan lama penyimpanan diperoleh rerata nilai rupa tertinggi pada perlakuan N2T3 (konsentrasi 18\% dan lama penyimpanan 2 hari) sebesar 6,39(cukup suka). Pada penyimpanan selama 2 hari dengan konsentrasi garam $18 \%$ diduga terjadi peresapan garam yang lebih sempurna kedalam daging kowoe sehingga menghasilkan daging kowoe memiliki tekstur yang lebih baik dengan warna coklat kehitaman yang disukai panelis. Warna yang dihasilkan pada penelitian ini yakni berwarna coklat kehitaman khas daging kowoe.

Organoleptik warna coklat kehitaman daging kowoe tersebut disebabkan oleh senyawa karbonil. Senyawa-senyawa karbonil dalam daging kowoe memiliki peranan pada pewarnaan. Hal ini sesuai 
dengan pendapat menurut Ruiter (1979), bahwa karbonil berfungsi sebagai pembentuk warna pada daging. Karbonil mempunyai efek terbesar pada terjadinya pebentukan warna coklat pada produk asapan. Jenis komponen karbonil yang paling berperan adalah aldehid glioksal dan metal glioksal sedangkan formaldehid dan hidroksiasetol memberikan peranan rendah. Selain itu warna coklat terjadi karena hasil reaksi Maillard yang dipengaruhi oleh beberapa faktor seperti kandungan gula reduksi, waktu serta temperatur pemanasan (Darmadji, 2006).

\section{Aroma}

Hasil analisis anova (analysis of variance) terhadap pengaruh interaksi konsentrasi garam dan lama penyimpanan diperoleh rerata nilai bau tertinggi pada perlakuan N2T3 (konsentrasi 18\% dan lama penyimpanan 2 hari) sebesar 6,39 (cukup suka). Pada penyimpanan selama 2 hari dengan konsentrasi garam $18 \%$ diduga terjadi peresapan garam yang lebih sempurna kedalam daging kowoe sehingga menghasilkan bau khas daging kowoe yang disukai panelis. Bau yang dihasilkan pada penelitian ini yakni bau amis khas daging kowoe.

Bau produk pangan berasal dari molekul-molekul yang mudah menguap dari makanan tersebut yang ditangkap oleh hidung sebagai indra pembau. Komponen yang memberikan aroma adalah asamasam organik berupa ester dan volatil. Secara kimiawi sulit dijelaskan mengapa senyawa-senyawa menyebabkan bau yang berbeda, karena senyawasenyawa yang mempunyai struktur kimia dan gugus fungsional yang hampir sama (stereoisomer) kadangkadang mempunyai bau yang sangat berbeda. Sebaliknya senyawa yang sangat berbeda struktur kimianya, mungkin menimbulkan bau yang sama (Winarno, 2004).

Dengan organoleptik bau khas daging kowoe disebabkan oleh senyawa fenol yang terkandung didalam daging keong kowoe. Fenol merupakan senyawa yang paling bertanggung jawab pada pembentukan aroma. Fenol dalam hubungannya dengan sifat sensoris mempunyai bau tajam menyengat. Meskipun Senyawa fenol memegang peranan penting dalam flavour makanan, namun diperlukan senyawa lain seperti karbonil. Girard (1992) menyatakan bahwa aroma daging yang terbentuk sebagian besar dipengaruhi oleh adanya senyawa fenol (siringol) dan karbonil serta sebagian kecil juga dipengaruhi oleh asam.

\section{Rasa}

Berdasarkan analisis ragam rerata nilai rasa pada daging keong kowoe menunjukkan bahwa tidak memberikan pengaruh nyata pada lama penyimpanan, tetapi memberikan pengaruh nyata terhadap analisis ragam konsentrasi garan dan interaksi perlakuan konsentrasi garan dan lama penyimpanan.

Organoleptik rasa khas daging keong kowoe disebabkan oleh adanya senyawa fenol. Senyawasenyawa fenol dalam daging memiliki peranan pada citarasa produk daging kowoe. Menurut Guillen (2000), menambahkan bahwa senyawa fenol sangat penting dalam produk daging, karena fenol berperan dalam menyumbangkan rasa spesifik.

Berdasarkan data tersebut dapat diketahui bahwa daging kowoe dengan konsentrasi garam 9\% dan lama penyimpanan 1 hari menghasilkan rasa khas daging kowoe. Adapun pada konsentrasi $27 \%$ dengan lama penyimpanan 2 hari belum menarik perhatian panelis. Hansen et al (1995) melaporkan bahwa dengan semakin tinggi kadar garam akan memberikan masa simpan yang lebih lama, namun kadar garam yang tinggi akan mengakibatkan nilai sensoris yang tidak baik seperti rasa yang asin, tekstur yang keras.

Menurut Yulstiani (2008), citarasa spesifik yang dimiliki produk pengasapan datang dari senyawa fenol di fase uap asap, yang diserap oleh permukaan produk. Senyawa fenol yang dikaitkan dengan bau dan citarasa spesifik tersebut adalah guaiakol, 4metilguaiakol dan 2,6-dimetoksi fenol. Kesemuanya merupakan penyusun utama fase uap maupun fase partikel pada asap.

\section{Tekstur}

Pada penyimpanan selama 2 hari dengan konsentrasi garam 18\% diduga terjadi peresapan garam yang lebih sempurna kedalam daging kowoe 
sehingga menghasilkan tekstur daging kowoe yang disukai panelis. Tekstur yang dihasilkan pada penelitian ini yakni terlihat struktur daging yang kompak. Rahmani, et al. (2007) melaporkan bahwa rata-rata tingkat kesukaan panelis terhadap tekstur daging cenderung meningkat dengan meningkatnya konsentrasi garam dan lama penyimpanan, perlakuan tersebut menyebabkan daging terlihat lebih kering karena kadar air yang rendah. Menurut Sofiyato (2001), bahwa penggunaan garam yang bersifat higroskopis.

\section{Kandungan kimia}

Tabel 2. Rekapitulasi hasil rerata kandungan kimia.

\begin{tabular}{lccccccccc}
\hline & \multicolumn{10}{c}{ Perlakuan } \\
\cline { 2 - 10 } \multicolumn{1}{c}{ Parameter } & NIT1 & N1T2 & N1T3 & N2T1 & N2T2 & N2T3 & N3T1 & N3T2 & N3T3 \\
\hline Kadar air & 74,23 & 74,12 & 4,11 & 79,54 & 79,43 & 79,31 & 83,34 & 82,29 & 82,18 \\
Kadar abu & 5,24 & 5,39 & 5,43 & 6,40 & 6,48 & 6,53 & 7,14 & 7,21 & 7,23 \\
Kadar protein & 14,44 & 14,26 & 14,21 & 12,43 & 12,39 & 12,29 & 10,17 & 10,07 & 9,94 \\
Kadar lemak & 1,18 & 1,17 & 1,08 & 0,96 & 0,92 & 0,88 & 0,56 & 0,48 & 0,43 \\
Kadar karbohidrat & 4,79 & 4,66 & 4,51 & 5,73 & 5,64 & 5,51 & 6,87 & 6,47 & 6,25 \\
\hline
\end{tabular}

\section{Kadar Air}

Berdasarkan hasil analisis ragam kadar air terhadap pengaruh konsentrasi garam memberikan pengaruh sangat nyata. Rerata nilai kadar air tertinggi diperoleh pada perlakuan N3T1 (konsentrasi 27\%) sebesar 83,34. Hal ini menunjukkan bahwa kadar garam dengan konsentrasi berpengaruh terhadap kadar air. Kadar air dalam penelitian ini tidak berbanding lurus dengan penelitian yang dilakukan oleh Hasan dan Edison (2007) kadar garam berhubungan dengan kadar air tersebut dimana semakin besar penambahan kadar garam akan terjadi pengurangan kadar air dalam daging.

\section{Kadar Abu}

Berdasarkan hasil analisis ragam interaksi konsentrasi kadar garam dan lama penyimpanan memberikan pengaruh sangat nyata. Rerata nilai kadar abu tertinggi diperoleh pada perlakuan N3T3 (konsentrasi 27\% dan lama penyimpanan 2 hari) sebesar 7,23 dan rerata kadar abu terendah diperoleh pada perlakuan N1T1 (konsentrasi 9\% dan lama penyimpanan 0 hari) sebesar 5,24. tingginya konsentrasi garam tentu dapat meningkatkan kadar abu, Kadar abu menggambarkan banyaknya mineral yang tidak terbakar menjadi zat yang mudah menguap.

Keong memiliki kandungan mineral yang beragam. Beragamnya kandungan mineral pada berbagai jenis keongdisebabkan oleh perbedaan spesies, habitat dan umur (Krzynowek dan Murphy 1987). Setiap organisme memiliki kemampuan yang berbeda dalam mengeluarkan dan mengabsorbsi logam, hal ini nantinya akan mempengaruhi kadar abu dalam bahan.

\section{Kadar Lemak}

Berdasarkan hasil analisis ragam interaksi konsentrasi kadar garam dan lama penyimpanan memberikan pengaruh sangat nyata. Rerata nilai kadar lemak tertinggi diperoleh pada perlakuan N1T1 (konsentrasi 9\% dan lama penyimpanan 0 hari) sebesar 1,28 dan rerata kadar lemak terendah diperoleh pada perlakuan N3T3 (konsentrasi 27\% dan lama penyimpanan 2 hari) sebesar 0,43.

Rahayu et al (1992) bahwa bila kadar air daging menurun, maka kadar lemaknya akan meningkat. Penambahan garam menyebabkan kadar air daging mengalami penurunan. Hal ini menyebabkan kadar lemak dendeng cenderung meningkat. Lemak tidak larut dalam air, sehingga semakin banyak air keluar 
dari daging akan menyebabkan kecenderungan kadar lemak daging meningkat. Hal ini sesuai dengan pendapat Kurniawan (2008) yang menyatakan, bahwa kadar lemak memiliki hubungan yang negatif dengan kadar air, artinya apabila kadar air menurun maka komponen lain misalnya lemak akan meningkat.

\section{Kadar Protein}

Berdasarkan hasil analisis ragam kadar protein terhadap pengaruh konsentrasi garam memberikan pengaruh sangat nyata. Rerata nilai kadar protein tertinggi diperoleh pada perlakuan N1T1 (konsentrasi $9 \%)$ sebesar 14,44 . Peningkatan kadar protein juga tidak berhubungan langsung dengan peningkatan kadar garam, namun dipengaruhi oleh pengurangan kadar air.

Menurut Winarno (1997), denaturasi protein dapat terjadi akibat adanya panas, $\mathrm{pH}$, bahan kimia, mekanik, dan lain sebagainya. Masing-masing cara tersebut mempunyai pengaruh yang berbeda-beda terhadap denaturasi protein. Hal ini senada dengan pernyataan Kasmadiharja (2008) bahwa penurunan nilai kadar protein disebabkan oleh rusaknya molekul protein yang disebabkan oleh proses degradasi selama penyimpanan. Degradasi protein terjadi karena adanya pengaruh panas, aktifitas mikroba, $\mathrm{pH}$ dan reaksi kimia enzimatis yang berlangsung selama penyimpanan.

Kadar garam juga memberikan pengaruh yang nyata terhadap kadar lemak daging kowoe yang dihasilkan, dimana semakin tinggi kadar garam, semakin rendah kadar lemak daging keong kowoe. Peningkatan kadar garam menurunkan kadar air; dan penurunan kadar air tersebut akan meningkatkan kadar protein. Hal ini sesuai dengan penelitian Hasan dan Edison (2007) yang melaporkan bahwa kadar air berbanding terbalik dengan kadar protein; dengan menurunnya kadar air, kadar protein akan meningkat.

\section{Kadar Karbohidrat}

Berdasarkan hasil analisis ragam kadar karbohidrat terhadap pengaruh konsentrasi garam memberikan pengaruh sangat nyata. Rerata nilai kadar karbohidrat tertinggi diperoleh pada perlakuan N3T1 (konsentrasi 27\%) sebesar 6,87.Karbohidrat merupakan sumber kalori utama. Di dalam tubuh karbohidrat berguna untuk memecah timbulnya ketosis, pemecahan protein yang berlebihan, kehilangan mineral, dan berguna untuk membantu metabolisme lemak dan protein. Dalam tubuh manusia karbohidrat dapat dibentuk dari beberapa asam amino dan sebagian dari gliserol lemak (Winarno, 1992).

\section{KESIMPULAN}

Hasil penelitian analisis ragam keong kowoe terhadap interaksi konsentrasi garam dan lama penyimpanan terhadap parameter uji nilai rupa, bau dan tekstur tidak memberikan pengaruh nyata dari semua indikator penilaian. Parameter uji nilai rasa memberikan pengaruh sangat nyata terhadap konsentrasi garam dan interaksi konsentrasi garam dan lama penyimpanan, sedangkan kadar air, abu, protein, lemak dan karbohidrat memberikan pengaruh sangat nyata dari semua indikator pengujian.

\section{DAFTAR PUSTAKA}

AOAC. 2005. Offivall Methods of Analysis. 18th ed. Association Offical Analytical Chemists, Washington DC.

Edison. 2007. Karekteristik Kimia dan Sensoris Fillet Asap yang Dibuat dari Ikan Patin (Pangasius hypophthalmus) dari Berbagai Ukuran. Jurnal Perikanan dan Kelautan No. 2.

Darmadji, P., K.R. Wulandari, dan U. Santoso. 2006. Sifat Antioksidatis Asap Cair Hasil Redistilasi Selama Penyimpanan. Prosiding Seminar Nasional Pangan. Pusat Antar Universitas Pangan dan Gizi UGM. Yoyakarta.

Girard. 1992. "Smoking in : Technology of Meat Product". Translated by Bernard Hammings and ATT. Clermont Ferrand. Ellis Horwood, New York. 165-205

Guillen, M.C., J. Turnay, M.D. Fernandez-Diaz, N. Imo, M.A. Lizarbe and P. Montero. 2002. Structural and Physical Properties of Gelatin Extracted from Different Marine Species: A Comparative Study. Food Hydrocolloids. 16: 25-34.

Hansen,L, T., Gill, T., dan Huss, H, H., 1994. Effect of salt and storagw temperature on chemical, microbiological and sensory changes in cold smoked salmon. Food research international, 
vol 28. Canadian Institute of Food Science anf Technology.

Hasan, B dan Edison. 2007. Karekteristik Kimia dan Sensoris Fillet Asap yang Dibuat dari Ikan Patin (Pangasius hypophthalmus) dari Berbagai Ukuran. Jurnal Perikanan dan Kelautan No. 2.

Kasmadiharja, H. 2008. Kajian Penyimpanan Sosis, Naget Ayam dan Daging Ayam Berbumbu dalam Kemasan Polipropilen Rigid. Skripsi. Fakultas Teknologi Pertanian. Institut Pertanian Bogor. Bogor.

Krzynowek, J., Murphy J. 1987. Proximate Composition, Energy, Fatty Acid, Sodium and Cholesterol Content of Finfish, Shellfish, and their Products. America: Departement of Commerce.

Kurniawan, E. 2008. Karakteristik Kimia Dendeng Daging Sapi Iris atau Giling Yang Difermentasi oleh Bakteri Asam Laktat Lactobacillus Plantarum 1b1. Skripsi.

Patang dan Yunarti, 2014. Penyidikan Spektrometrik Senyawa Organik. Edisi Keempat. Jakarta : Erlangga.

Rahayu, P. W., S. Ma'oen, Suliantari, dan S. Fardiaz. 1992. Teknologi Fermentasi Produk Perikanan. Institut Pertanian Bogor.

Rahmani, Yunianta, Martati, E. 2007. Pengaruh Metode Penggaraman Basah Terhadap Karakteristik Ikan Asin Gabus (Ophiocephalus Striatus). Jurnal Teknologi Pertanian. Volume 8 Nomor 3 (Desember 2007).

Ruiter, A. 1979. Fish and Fishery Products, Composition, Nutritive Properties and Stability. Singapura: Cab International.

Safrullah, 2003. Tips Pangan Tekhnologi Nutrisi dan Keamanan Pangan. Jakarta: PT Gramedia Widiasarana Indonesia.

Sofiyanto. 2001. Penggunaan Berbagai Jenis Bahan Kemasan Dalam Mempertahankan Mutu Ikan Asin Patin (Pangasius Hypophthalmus) Selama Penyimpanan.

Wardhono, W., 2012, Pengaruh Rasio Penggunaan Daging Tutut dan Daging Sapi Terhadap Sensori Bakso Tutut, Skripsi, Universitas Bandung Raya.

Winarno, FG. 2008. Bahan Tambahan Untuk Makanan dan Kontaminan. Jakarta: Gramedia . 1992. Pangan, Gizi, Teknologi dan Konsumen. PT Gramedia Pustaka Utama.
Jakarta.

2004. Kimia Pangan dan Gizi. Penerbit PT Gramedia Pustaka Utama. Jakarta.

Yulstiani, R. 2008. Monograf Asap Cair sebagai Bahan Pengawet Alami pada Produk Daging dan Ikan. Cetakan Pertama. Edisi 1. UPN Veteran Jawa Timur. Surabaya 